\title{
PENGAMBILAN KEPUTUSAN GENDER RUMAH TANGGA PETANI PADA BUDIDAYA TANAMAN PADI SAWAH SISTEM SUBAK DI PERKOTAAN
}

\author{
Gender Decision Making of Farmers' Household \\ On Rice Cultivation of Subak System in Urban
}

\author{
Wayan Sudarta \\ Program Studi Agribisnis, Fakultas Pertanian, Universitas Udayana, Bali, Indonesia
}

Email: sudarta@unud.ac.id

\begin{abstract}
This study aims to determine the types of gender decision-making (husband and wife) on a variety of rice cultivation activities based on subak system in urban areas. The research took the location of research in Subak Anggabaya, East Denpasar District, Denpasar City as a case study. The results of this study indicate that the activities of the subak system of decision-making type with the dominant wife, is generally applicable in the field of collective decision-making activities of the ritual. The husband's own decision-making type without negotiating with wives, is common in four areas of the five decision areas. Then in the household activities of farmers, most of the decision-making area (77\%) is common type of decision-making husband himself, without negotiating with his wife.
\end{abstract}

Keywords: gender, decision making, subak

\section{ABSTRAK}

Penelitian ini bertujuan untuk mengetahui tipe pengambilan keputusan gender (suami-istri) pada beragam kegiatan budidaya tanaman padi sawah yang berbasis sistem subak di perkotaan. Penelitian mengambil lokasi penelitan di Subak Anggabaya, Kecamatan Denpasar Timur, Kota Denpasar sebagai suatu studi kasus. Hasil penelitian ini menunjukkan bahwa pada kegiatan sistem subak tipe pengambilan keputusan bersama istri dominan, umum berlaku pada bidang pengambilan keputusan kegiatan ritual secara kolektif. Tipe pengambilan keputusan suami sendiri tanpa berunding dengan istri, umum terjadi pada empat bidang dari lima bidang pengambilan keputusan. Kemudian pada kegiatan rumah tangga petani, sebagian besar dari bidang pengambilan keputusan (77\%) umum terjadi tipe pengambilan keputusan suami sendiri, tanpa berunding dengan istri.

Kata Kunci: gender, pengambilan keputusan, subak

\section{PENDAHULUAN}

\section{Latar Belakang}

Sejatinya, berbicara tentang gender berarti berbicara tentang pria dan wanita di luar kodrat. Gender diartikan sebagai konstruksi sosial yang dikenakan kepada pria dan wanita yang dibangun oleh kebudayaan atau kultural masyarakat. Gender dapat pula diartikan sebagai peran dan tanggung jawab pria dan wanita yang dibentuk oleh norma sosial dan nilai budaya masyarakat (Sudarta, 2016).

Berdasarkan pemahaman tersebut, peran gender merupakan peran sosial yang tidak ditentukan oleh perbedaan jenis kelamin sebagaimana halnya peran kodrat (anugrah Tuhan) yang bersifat abadi. Dengan demikian, peranan gender dapat berbeda antara satu masyarakat dengan masyarakat lainnya, sesuai dengan lingkungan. Peran gender dapat berubah dari masa ke masa karena pengaruh kemajuan, baik kemajuan di bidang ekonomi, pendidikan dan teknologi maupun di bidang lainnya. Hal tersebut berarti, peranan gender dapat dipertukarkan antara pria dengan wanita.

Bali yang walaupun menganut sistem kekerabatan patrilineal, yang menempatkan pria pada posisi yang lebih tinggi atau lebih berkuasa daripada wanita, tidak menutup kemungkinan peranan pria dan wanita khususnya peranan dalam pengambilan keputusan pada bidang-bidang tertentu, dapat mengalami perubahan, atau dapat dipertukarkan. Berkaitan dengan pengambilan keputusan dalam suatu rumah tangga, dinyatakan oleh Sudarta

Sudarta, Pengambilan Keputusan....|59 
(2006), bahwa kepala rumah tangga, yaitu suami (pria) dan istrinya (wanita) merupakan simbol yang paling dihormati dan pemegang kekuasaan tertinggi atau merupakan sentral pengambilan keputusan dalam rumah tangga, yang sangat mempengaruhi kelangsungan hidup anggota rumah tangga mereka.

Kiranya perlu diketahui bahwa ada tiga faktor utama yang mempengaruhi gender (suami-istri) suatu rumah tangga, termasuk rumah tangga petani dalam pengambilan keputusan, seperti yang akan dijelaskan berikut ini.

(1) Perkawinan (pernikahan)

Status dan peranan wanita yang normal dalam masyarakat sebagai istri. Biasanya seorang istri umurnya lebih muda dan pendidikannya lebih rendah daripada suami. Karena suami dianggap lebih tua, secara tidak langsung mempengaruhi istri dalam pengambilan keputusan (Sajogyo, 1984). Adanya adat dalam perkawinan (terutama pada masyarakat patrilineal), istri mengikuti suami atau tinggal di pihak kerabat suami, secara relatif cenderung pula mempengaruhi status istri (wanita) dalam pengambilan keputusan, yakni pengambilan keputusannya menjadi lebih lemah daripada suami (pria).

(2) Pewarisan

Dinyatakan oleh Goodi (dalam White dan Hastuti, 1980) bahwa dalam masyarakat (terutama masyarakat yang menganut sistem kekerabatan patrilineal), wanita tidak bisa menjadi pemilik tanah atau kekayaan yang lain melalui hak waris, status wanita cenderung menjadi lebih lemah daripada pria. Keadaan itu berimplikasi pada lemahnya istri dalam pengambilan keputusan.

(3) Sumberdaya Pribadi

Sumber daya pribadi yang disumbangkan oleh suami atau istri ke dalam rumah tangga mereka, dapat pula mempengaruhi pengambilan keputusan. Sumber daya pribadi itu dapat berupa pendidikan, keterampilan, uang, tanah atau lahan pertanian, pengetahuan ritual, dan sebagainya (Blood dan Wolfe dalam Sudarta dan Artini, 1999). Suami atau istri yang memiliki sumber daya pribadi yang lebih tinggi, dapat mendominasi posisinya dalam pengambilan keputusan pada bidang-bidang tertentu.

Berdasarkan pemikiran tersebut, kiranya menarik untuk dikaji melalui suatu mikro, bagaimana pengambilan keputusan gender (pria dan wanita) rumah tangga petani berkaitan dengan budidaya tanaman padi sawah yang berbasis sistem subak di perkotaan.

\section{Rumusan Masalah}

Berdasarkan latar belakang di atas maka dalam penelitian ini masalah yang diajukan adalah bagaimana pengambilan keputusan gender pada rumah tangga petani pada budidaya tanaman padi sistem subak

\section{Tujuan Penelitian}

Sebagaimana disampaikan melalui rumusan di atas maka tujuan yang ingin dicapai dalam penelitian ini adalah untuk mengetahui sistem pengambilan keputusan di tingkat rumah tangga petani pada budidaya tanaman padi di sistem subak.

\section{KAJIAN PUSTAKA}

\section{Pengertian Rumah Tangga Pertanian}

Rumah tangga adalah seseorang atau sekelompok orang yang mendiami sebagian atau seluruh bangunan fisik serta biasanya tinggal bersama dan mengkonsumsi makanan yang berasal dari satu dapur, di mana biasanya kebutuhan sehari-hari anggotanya dikelola menjadi satu. Adapun yang dimaksud dengan rumah tangga pertanian adalah rumah tangga yang sekurang-kurangnya satu anggota rumah tangga melakukan kegiatan bertani atau berkebun, menanam tanaman, beternak, dan lain-lain dengan tujuan sebagian atau seluruh hasilnya dijual untuk memperoleh pendapatan ataupun keuntungan atas resiko sendiri. Dengan demikian, yang dimaksud dengan rumah tangga usahatani adalah rumah tangga yang salah satu atau lebih anggotanya mengolah lahan pertanian, baik lahan sawah maupun lahan kering, membudidayakan tanaman pertanian, melakukan pengambilan hasil lahan pertanian dengan tujuan sebagian atau seluruh hasilnya dimanfaatkan sendiri atau dijual untuk memperoleh pendapatan ataupun keuntungan atas resiko sendiri (Pratiwi 2007).

\section{Gender dan Kesetaraan Gender}

Secara mendasar, gender berbeda dari jenis kelamin biologis, konsep gender berbeda dengan jenis kelamin. Handayani dan Sugiarti (2008) menyatakan bahwa jenis kelamin (seks) adalah pembagian jenis kelamin yang ditentukan secara biologis melekat pada jenis kelamin tertentu. Lebih lanjut Handayani menjelaskan, seks berarti perbedaan laki-laki dan perempuan sebagai makhluk yang secara kodrati memiliki fungsi-fungsi organisme yang berbeda. Secara biologis alat-alat biologis tersebut melekat pada laki-laki dan perempuan selamanya, fungsinya tidak dapat dipertukarkan. Secara permanen tidak berubah dan merupakan ketentuan biologi atau ketentuan Tuhan (kodrat). Karena itu, Handayani dan Sugiarti (2008) menyatakan bahwa konsep gender adalah sifat yang melekat pada kaum laki-laki dan perempuan yang dibentuk oleh faktor-faktor sosial maupun budaya, sehingga lahir beberapa angggapan tentang peran sosial dan budaya laki-laki dan perempuan. Begitu pula yang dikemukakan oleh Mugniesyah (2006) bahwa konsep gender adalah perbedaan sifat lakilaki dan perempuan yang dikonstruksikan oleh sistem nilai budaya dan struktur sosial. Bentukan 
sosial atas laki-laki dan perempuan itu antara lain: kalau perempuan dikenal sebagai makhluk yang lemah lembut, cantik, emosional, atau keibuan. Sedangkan laki-laki dianggap kuat, rasional, jantan, dan perkasa. Sifat-sifat di atas dapat dipertukarkan dan berubah dari waktu ke waktu, sehingga dapat dikatakan bahwa gender dapat diartikan sebagai konsep sosial yang membedakan (dalam arti: memilih atau memisahkan) peran antara laki-laki dan perempuan. Perbedaan fungsi dan peran antara laki-laki dan perempuan itu tidak ditentukan antara keduanya terdapat perbedaan biologis atau kodrat, tetapi dibedakan atau dipilah-pilah menurut kedudukan, fungsi dan peranan masing-masing dalam berbagai bidang kehidupan dan pembangunan.

Mugniesyah (2006) menambahkan bahwa perbedaan gender antara laki-laki dan perempuan ini terjadi melalui proses yang amat panjang. Melalui proses yang amat panjang inilah maka gender dianggap sebagai kodrat Tuhan yang tidak dapat diubah lagi. Perbedaan peran gender ini akan menimbulkan pembagian kerja yang berbeda pula antara laki-laki dan perempuan yang disebut dengan pembagian kerja gender. Pembagian kerja gender ini tercermin dalam tiga peran gender yaitu reproduktif, produktif, dan sosial. Peran reproduktif adalah kegiatan yang berkaitan dengan melahirkan dan mempersiapkan keperluan keluarga tiap harinya. Peran produktif adalah kegiatan yang menghasilkan produksi barang atau jasa, untuk dikonsumsi sendiri atau dijual. Sedangkan peran sosial adalah yang mencakup kegiatan sosial dan gotong royong dalam kehidupan masyarakat.

\section{Pola Pengambilan Keputusan dalam Rumah Tangga}

Pengambilan keputusan merupakan permulaan dari aktifitas manusia yang sadar dan terarah, baik secara individu, kelompok atau institusional, sehingga pengambilan keputusan manjadi aspek yang penting dalam suatu pengelolaan atau manajemen. Pola pengambilan keputusan dalam rumah tangga akan berpengaruh terhadap bagaimana terjadinya struktur dalam rumah tangga, lebih dalam lagi dapat melihat siapa yang paling berhak mengambil keputusan dalam rumah tangga atas dasar kekuasaanya. Kekuasaan dinyatakan sebagai kemampuan untuk mengambil keputusan yang dapat mempengaruhi kehidupan rumah tangga itu.

Pengaruh lingkungan luar rumah masyarakat pada umumnya bisa memperkaya dan dapat menambah wawasan perempuan yang diperkirakan dapat mengembangkan potensinya dalam pengambilan keputusan di berbagai bidang kehidupan dalam rumah tangga. Selain itu, faktor pendidikan perempuan serta personal berupa pengalamannya bergaul dengan masyarakat luas hal yang menimbulkan potensi perempuan semakin besar dalam pengambilan keputusan dalam rumah tangga.

Olsson (1997) menyatakan bahwa terdapat tiga bidang yang berbeda dalam menganalisa konsep kekuasaan dalam keluarga: dasar kekuasaan, proses kekuasaan dalam keluarga, dan hasil kekuasaan dalam keluarga. Berdasarkan hal tersebut, pengambilan keputusan ada pada bidang kedua dan ketiga sehingga pengambilan keputusan dapat diartikan sebagai perwujudan proses yang terjadi dalam keluarga dan merupakan hasil dari interaksi anggota keluarga untuk saling mempengaruhi sehingga terbentuk pola pengambilan keputusan berdasarkan peran dan bidang keputusannya.

Perempuan sebagai pengambil keputusan dalam keluarga tidak lepas dari perannya dalam keluarga. Norma yang diakui menyatakan bahwa yang paling sering menentukan keputusan dalam keluarga adalah suami. Pada kenyatannya terdapat banyak variasi tentang pengambilan keputusan dalam keluarga. Terkadang memang perempuan tidak diikutsertakan, namun tidak menutup kemungkinan bahwa perempuan juga ikut dalam menentukan keputusan baik sendiri maupun bersama suami. Sajogyo (1993) menyatakan bahwa faktor-faktor yang dianggap mempengaruhi perempuan dalam pengambilan keputusan adalah: proses sosialisasi, pendidikan, latar belakang perkawinan, kedudukan dalam masyarakat, dan pengaruh luar lainnya.

\section{METODE PENELITIAN}

\section{Lokasi dan Waktu Penelitian}

Penelitian ini dilakukan di Subak Anggabaya, Kecamatan Denpasar Timur, Kota Denpasar. Pemilihan lokasi penelitian ini dilakukan secara sengaja dengan pertimbangan sebagai berikut. (1) Subak ini direncanakan oleh Pemerintah Kota Denpasar sebagai subak lestari dan aggota subak tersebut sudah sepakat dan siap mewujudkan rencana tersebut. (2) Rumah tangga petani yang menjadi anggota Subak Anggabaya, semuanya aktif bertani di sawah dan melaksanakan inovasi pertanian sesuai dengan anjuran. (3) Memiliki panorama alam yang indah, berbatasan dengan persawahan Kabupaten Badung yang terhampar luas. (4) Subak Anggabaya potensial dijadikan agrowisata, sehingga merupakan "gayung bersambut" dengan rencana subak lestari. Penelitian ini dilakukan pada bulan Juni 2017. Namun, pengumpul data atau peneliti tidak sepenuhnya di lapang pada bulan tersebut.

\section{Pemilihan Rumah Tangga Petani Contoh dan Responden}

Pasangan suami-istri rumah tangga petani merupakan unit analisis dalam penelitian ini. Jumlah rumah tangga petani contoh atau pasangan suami-istri responden yang dianggap paling bertanggung jawab dalam rumah tangga tersebut sebanyak 20 rumah tangga atau pasangan suami- 
istri, yang diambil secara acak dari frame sampling berupa daftar nama anggota subak pada Pekaseh Subak Anggabaya. Pengambilan secara acak 20 rumah tangga petani contoh tersebut, dengan pertimbangan penguasaan lahan pertanian petani yang menjadi anggota Subak Anggabaya berkisar antara 35-50 are, yang berarti dianggap relatif homogen. Berdasarkan data ini diasumsikan keadaan sosial-ekonomi rumah tangga petani anggota Subak Anggabaya, juga relatif homogen. Dengan demikian, pengambilan 20 rumah tangga petani contoh atau 20 pasang suami-istri responden dianggap sudah cukup dalam penelitian ini.

\section{Pengumpulan Data}

Data yang dikumpulkan dalam penelitian ini meliputi data primer dan data sekunder, yang terdiri atas data kuantitatif dan kualitatif. Data primer dikumpulkan melalui mekanisme wawancara kepada responden dengan menggunakan instrumen berupa daftar pertanyaan terstruktur, sedangkan data sekunder dikumpulkan melalui dokumen tertulis.

Data primer yang dicari mencakup (1) umur responden (dalam tahun), (2) pendidikan formal responden (dalam tahun), (3) luas pemilikan dan penguasaan lahan pertanian dan pekarangan (dalam are), (4) tipe pengambilan keputusan gender (suamiistri) rumah tangga petani dalam budidaya tanaman padi sawah (dalam persen). Data sekunder yang dicari terbatas hanya untuk kepentingan pengambilan rumah tangga contoh dan responden.

\section{Analisis Data}

Data yang terkumpul dianalisis secara deskriptif kualitatif, dengan bantuan tabulasi silang. Data tentang pengambilan keputusan gender (suami-istri) dianalisis ke dalam lima tipe pengambilan keputusan menurut pemikiran Pudjiwati Sajogyo (1984) sebagai berikut:

(1) Pengambilan keputusan yang dilakukan oleh istri sendiri, tanpa berunding dengan suami.

(2) Pengambilan keputusan bersama, tetapi pengaruh istri lebih dominan.

(3) Pengambilan keputusan bersama setara, tanpa ada yang mendominasi.

(4) Pengambilan keputusan bersama, tetapi pengaruh suami lebih dominan.

(5) Pengambilan keputusan yang dilakukan oleh suami sendiri, tanpa berunding dengan istri.

\section{HASIL DAN PEMBAHASAN}

Hasil dan pembahasan dalam tulisan ini, dibagi menjadi dua bagian, yakni ciri-ciri rumah tangga petani dan pegambilan keputusan gender rumah tangga petani.

\section{Ciri-ciri Rumah Tangga Petani}

Ciri-ciri rumah tangga petani contoh di Subak Anggabaya tertuang pada Tabel 1 .

Tabel 1. Ciri-ciri Rumah Tangga Petani Contoh di Subak Anggabaya, Kecamatan Denpasar Timur, Kota Denpasar Tahun 2017.

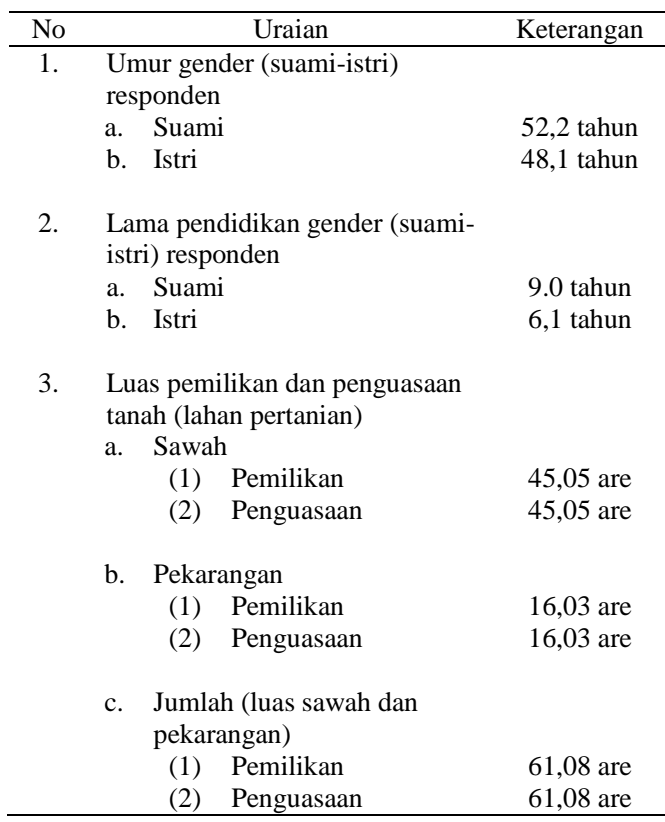

Berdasarkan data yang tersaji pada Tabel 1 dapat dipahami sebagai berikut. (1) Rata-rata umur suami 52,2 tahun, sedangkan umur istri 48,1 tahun, yang berarti umur suami 4,1 tahun lebih tua daripada umur istri. (2) Pendidikan formal yang berhasil dikenyam oleh suami selama sembilan tahun atau setara dengan tamatan Sekolah Menengah Pertama (SMP), sedangkan pendidikan formal yang berhasil dikenyam oleh istri selama 6,1 tahun, atau setara dengan tamatan Sekolah Dasar (SD). Data ini menunjukkan pendidikan formal suami lebih tinggi daripada pendidikan formal istri. (3) Seluruh lahan sawah dan pekarangan rumah tangga petani contoh seluas 61,08 are, terbagi menjadi sawah seluas 45,05 are $(74 \%)$ dan pekarangan seluas 16,03 are (26\%). Semuanya merupakan lahan milik yang digarap, tanpa menggarap lahan petani lain dan tanpa menggarapkan lahan miliknya sendiri kepada petani lain.

\section{Pengambilan Keputusan Gender Rumah Tangga Petani}

Secara umum dapat dikatakan, bahwa pengambilan keputusan identik dengan kekuasaan. Kekuasaan dalam rumah tangga dapat diartikan sebagai suatu kemampuan suami (pria) atau istri (wanita) untuk menentukan sesuatu dalam rumah tangga mereka yang mempengaruhi kehidupan rumah tangga tersebut (Sudarta, 2011). 
Pengambilan keputusan gender (suami-istri) rumah tangga petani pada beragam pekerjaan budidaya tanaman padi sawah garapan sendiri yang berbasis sistem subak, yang akan dibahas berikut ini, dikelompokkan menjadi dua, yakni yang berkaitan dengan kegiatan subak dan yang berkaitan dengan kegiatan rumah tangga petani. Pengambilan keputusan gender (suami-istri) tersebut dapat dari sebelah kiri ke sebelah kanan dalam Tabel 2. Hasilhasil yang diperoleh pada tabel tersebut, nilai tertinggi pada setiap baris dicetak tebal. Hal itu dimaksudkan, untuk memudahkan pemahaman pembaca mengenai pola dasar hasil-hasil yang diperoleh.

Berdasarkan lima tipe pengambilan keputusan gender (suami-istri) seperti telah diuraikan sebelumnya, melalui data yang tersaji pada Tabel 2 dapat dipahami hal-hal sebagai berikut.

\section{Kegiatan Subak}

Berkaitan dengan kegiatan subak (tempek/munduk, subak, dan lainnya, kegiatan lembaga yang lebih luas), ternyata empat dari lima bidang pengambilan keputusan, yang mencakup rapat-rapat, gotong royong (perbaikan dan pembersihan jaringan irigasi, fasilitas lainnya selain jaringan irigasi), penyuluhan pembangun pertanian, dan pengadopsian inovasi pertanian, umum berlaku "tipe pengambilan keputusan suami sendiri, tanpa berunding dengan istri". Persentase yang dicapai oleh tipe pengambilan keputusan ini berkisar antara $80 \%$ s.d $90 \%$. Hal ini tentu saja tidak terlepas atau berkaitan erat dengan sistem kekerabatan patrilineal yang dianut oleh masyarakat setempat, yang menempatkan posisi suami (pria) lebih tinggi daripada istri (wanita).

Pria umumnya memiliki sumber daya pribadi yang lebih tinggi daripada wanita yang diperoleh melalui hak waris berupa kekayaan, sedangkan wanita tidak mempunyai hak wais seperti itu. Dengan demikian, keadaan itu memperlemah posisi wanita dalam pengambilan keputusan.

Namun, "tipe pengambilan keputusan bersama istri dominan" artinya istri berunding dengan suami, tetapi akhirnya ditentukan oleh istri, umum terjadi untuk kegiatan ritual secara kolektif (75\%). Hal ini tidak lain disebabkan oleh istri (wanita) mempunyai sumber daya pribadi yang lebih tinggi daripada suami (pria), yang berupa keterampilan membuat sesajen. Keadaan ini sejalan dengan yang dinyatakan oleh Blood dan Wolfe (dalam Sudarta dan Artini, 1999) seperti telah diuraikan sebelumnya. Diantaranya dinyatakan oleh mereka, bahwa sumber daya pribadi yang berupa keterampilan tertentu yang disumbangkan oleh suami (pria) dan istri (wanita) kepada rumah tangga mereka, dapat mempengaruhi pengambilan keputusan.

\section{Kegiatan Rumah Tangga Petani}

Berkaitan dengan pengambilan keputusan gender (suami-istri) rumah tangga petani, pada beragam kegiatan dalam satu siklus budidaya tanaman padi sawah garapan sendiri di Subak Anggabaya, berdasarkan data pada Tabel 2 dapat dijelaskan sebagai di bawah ini.

Tabel 2. Pengambilan Keputusan Gender Rumah Tangga Petani pada Budidaya Tanaman Padi Sawah Garapan sendiri dalam Semusim di Subak Anggabaya, Kecamatan Denpasar Timur, Kota Denpasar Tahun 2017.

\begin{tabular}{cll}
\hline No. & \multicolumn{1}{c}{ Uraian } & Keterangan \\
\hline 1. & $\begin{array}{l}\text { Umur gender (suami-istri) } \\
\text { responden }\end{array}$ & \\
& $\begin{array}{l}\text { c. Suami } \\
\text { d. Istri }\end{array}$ & 52,2 tahun \\
& & \\
2. & Lama pendidikan gender & \\
& (suami-istri) responden \\
& c. Suami & \\
& d. Istri & 9.0 tahun \\
&
\end{tabular}

3. Luas pemilikan dan penguasaan tanah (lahan pertanian)

d. Sawah
(3) Pemilikan
45,05 are
(4) Penguasaan
45,05 are

e. Pekarangan

(3) Pemilikan $\quad 16,03$ are

(4) Penguasaan 16,03 are

f. Jumlah (luas sawah dan pekarangan)
(3) Pemilikan
61,08 are
(4) Penguasaan
61,08 are

(1) Pengambilan keputusan istri sendiri, tanpa berunding dengan suami.

Tipe pengambilan keputusan istri sendiri tanpa berunding dengan suami, hanya terjadi pada satu bidang pengambilan keputusan, yaitu dalam kgiatan ritual $(80 \%)$. Kalaupun istri berunding dengan suami, pada akhirnya ditentukan oleh istri (tipe pengambilan keputusan bersama, tetapi pengaruh istri lebih dominan, sebanyak 20\%). Fakta tersebut memberikan gambaran, bahwa betapa pentingnya arti atau peranan wanita dalam kegiatan ritual pada budidaya tanaman padi sawah berbasis subak.

(2) Pengambilan keputusan bersama, tetapi pengaruh istri lebih dominan.

Tipe pengambilan keputusan seperti ini berlaku hanya untuk kegiatan ritual seperti telah diuraikan di atas. 
(3) Pengambilan keputusan setara, tanpa ada yang mendominasi.

Tipe pengambilan keputusan bersama setara, umum terjadi di lokasi penelitian hanya untuk bidang pengambilan keputusan penggunaan hasil panen (75\%). Keadaan ini menggambarkan, bahwa dalam penggunaan hasil panen padi sebagai bahan pangan utama, sudah terjadi kesepakatan atau hubungan yang harmonis antara suami (pria) dengan istri (wanita) rumah tangga petani.

(4) Pengambilan keputusan bersama, tetapi pengaruh suami lebih dominan.

Berkaitan dengan tipe pengambilan keputusan ini, sesungguhnya suami berunding dengan istri tetapi akhirnya ditentukan oleh suami. Tipe pengambilan keputusan tersebut, umum berlaku hanya pada bidang pengambilan keputusan penetapan tenaga kerja (75\%), yang dimanfaatkan dalam pekerjaan-pekerjaan tertentu pada budidaya padi sawah garapan sendiri. Tenaga kerja itu, umumnya berasal dari luar lokasi penelitian (Bali atau Jawa).

(5) Pengambilan keputusan suami sendiri.

Tipe pengambilan keputusan suami sendiri, tanpa berunding dengan istri, sangat umum terjadi pada 10 bidang dari 13 bidang pengambilan keputusan. Kesepuluh bidang pengambilan keputusan tersebut meliputi bidang pengambilan keputusan: (1) pengolahan lahan baik di persemaian maupun ditempat pertanaman (90\%); (2) persemaian (90\%); (3) pencabutan bibit di persemaian dan penanaman bibit di lapangan atau tempat pertanaman (75\%); (4) pengairan $(80 \%)$; (5) pemupukan (80\%); (6) penyiangan atau pengendalian rerumputan (75\%); (7) pengendalian hama/penyakit tumbuhan terpadu $(70 \%) ;(8)$ pengadaan sarana produksi padi (saprodi) meliputi bibit, pupuk, dan obat-obatan $(90 \%)$; (9) pengadaan alat-alat pertanian seperti cangkul, sabit, dan alat perontok padi $(90 \%)$; dan (10) panen dan pengangkutan (70\%).

Fakta tersebut mencerminkan, bahwa dalam pengambilan keputusan gender (suami-istri) rumah tangga petani pada beragam kegiatan budidaya tanaman padi sawah di Subak Anggabaya, masih dipengaruhi oleh sistem kekerabatan patrilineal yang dianut oleh masyarakat setempat. Kalaupun ada pergeseran, yang mengarah pada pengambilan keputusan bersama (setara), maka pergeseran itu relatif kecil, yakni berkisar antara 5\% s.d 25\%. Kecuali pengambilan keputusan gender (suami-istri) rumah tangga petani di bidang penggunaan hasil panen padi $(75 \%)$, yang sudah menunjukkan pengambilan keputusan bersama setara.

\section{SIMPULAN DAN SARAN}

Berdasarkan hasil dan pembahasan tersebut, dapat disimpulkan sebagai berikut. (1) Tipe pengambilan keputusan suami sendiri, umum terjadi baik dalam beragam kegiatan subak ( $80 \%$ s.d 90\%), maupun dalam beragam kegiatan rumah tangga petani pada budidaya tanaman padi sawah (70\% s.d $90 \%)$. (2) Tipe pengambilan keputusan istri sendiri, umum terjadi pada kegiatan rumah tangga petani di bidang pengambilan keputusan kegiatan ritual (80\%). (3) Tipe pengambilan keputusan bersama setara, dominan terjadi pada rumah tangga petani di bidang pengambilan keputusan penggunaan hasil panen (75\%). (4) Terakhir yang tidak kalah penting, tipe pengambilan keputusan bersama suami dominan, umum terjadi pada kegiatan rumah tangga petani di bidang pengambilan keputusan penetapan tenaga kerja yang digunakan dalam pekerjaan tertentu dalam budidaya tanaman padi sawah $(75 \%)$.

Keadaan tersebut rupanya membawa implikasi yang khas berkaitan dengan penyuluhan pembangunan pertanian dalam pelayanan yang dibutuhkan bagi rumah tangga petani, yaitu dapat ditujukan kepada sasaran yang tepat, suami (pria) atau istri (wanita) atau keduanya sebagai pihak-pihak yang membutuhkan sejalan dengan peranan mereka masing-masing.

\section{DAFTAR PUSTAKA}

Handayani dan Sugiarti. 2008. Konsep dan Teknik Penelitian Gender. Malang (ID): UMM Pr.

Mugniesyah S. 2006. "Gender, Lingkungan dan Pembangunan Berkelanjutan" dalam Ekologi Manusia. Editor Soeryo Adiwibowo. Bogor (ID): Institut Pertanian Bogor.

Olsson. 1997. Pembagian Kerja Seksual. Jakarta (ID): Gramedia Pustaka Utama.

Pratiwi N. 2007. Analisis Gender pada Rumah Tangga Petani Monokultur Sayur (Kasus Desa Sigorogunung, Kecamata Ngagoyoso, Kabupaten Karanganyar, Jawa Tengah). Skripsi: Institut Pertanian Bogor. Bogor (ID).

Pujawati Sajogyo. 1984. Teknologi Pertanian dan Peluang Kerja Wanita di Pedesaan (Suatu Kasus Pertanian Padi Sawah). Pusat Studi Pembangunan Lembaga Penelitian Institut Pertanian Bogor. Bogor.

Sajogyo P. 1993. Peranan Perempuan dalam Perkembangan Masyarakat Desa. Jakarta (ID): Yayasan Ilmu-ilmu Sosial.

Sudarta, W dan Artini, W.P. 1999. Distribusi Kekuasaan Suami-Istri Rumah Tangga 
Petani Lapisan Bawah pada Beragam Pekerjaan Pertanian Sawah dan Rumah Tangga. Agritop. Jurnal Ilmu-ilmu Pertanian (Journal On Agricultural Science). Vol18 No. 2 Denpasar 1999. Fakultas Pertanian Universitas Udayana, Denpasar.

Sudarta, Wayan. 2006. Pola Pengambilan Keputusan Suami-Istri Runah Tangga Petani pada Berbagai Bidang Kehidupan. Dalam Arjani, Ni Luh, N. Suparta. 2006. Kembang Rampai Perempuan Bali. CV. Karya Sasra. Denpasar.

Sudarta, Wayan. 2016. Sosiologi Pertanian. Udayana University Press. Denpasar.

White, B dan Hastuti, E.L. 1980. Pola Pengambilan Keputusan di Tingkat Rumah Tangga dan Masyarakat (Studi Kasus di Dua Desa di Jawa Barat). Kerjasama antara Menteri Urusan Peranan Perempuan. Studi Dinamika Pedesaan-SAE Bogor. Lembaga Penelitian Sosiologi Pedesaan IPB dan UNICEF. Bogor. 